\title{
Green Fodder Production and Water Use Efficiency of Some Forage Crops under Hydroponic Conditions
}

\author{
Ghazi N. Al-Karaki ${ }^{1}$ and M. Al-Hashimi² \\ ${ }^{1}$ Faculty of Agriculture, Jordan University of Science and Technology, Irbid 22110, Jordan \\ ${ }^{2}$ Sultan Qaboos Center for Developed and Soilless Agriculture, Arabian Gulf University, Manama, Bahrain
}

Correspondence should be addressed to Ghazi N. Al-Karaki, gkaraki@just.edu.jo

Received 6 September 2011; Accepted 26 September 2011

Academic Editor: H.-L. Xu

Copyright ( 2012 G. N. Al-Karaki and M. Al-Hashimi. This is an open access article distributed under the Creative Commons Attribution License, which permits unrestricted use, distribution, and reproduction in any medium, provided the original work is properly cited.

\begin{abstract}
The objectives of this study were to evaluate five forage crops (alfalfa (Medicago sativa), barley (Hordeum vulgare), cowpea (Vigna unguiculata), sorghum (Sorghum bicolor), and wheat (Triticum aestivum)) for green fodder production and water use efficiency under hydroponic conditions. The experiment has been conducted under temperature-controlled conditions $\left(24 \pm 1^{\circ} \mathrm{C}\right)$ and natural window illumination at growth room of Soilless Culture Laboratory, Arabian Gulf University, Manama, Bahrain. The results showed that green forage can be produced in 8 days from planting to harvest using hydroponic technique. Highest values for green fresh yields were recorded for the crops cowpea, barley, and alfalfa which gave 217, 200, and 194 tons/ha, respectively. However, only cowpea and barley crops gave the highest green dry yield, but not alfalfa. Barely crop used water more efficiently than the other four tested crops when produced about $654 \mathrm{~kg}$ fresh matter $/ \mathrm{m}^{3}$ water in comparison to $633,585,552$, and $521 \mathrm{~kg}$ fresh matter $/ \mathrm{m}^{3}$ water for cowpea, sorghum, wheat, and alfalfa, respectively. No significant differences between barley and cowpea for water use efficiency were noted. It can be concluded from this study that barley crop can be considered the best choice for production of hydroponic green fodder with less water consumption.
\end{abstract}

\section{Introduction}

Reducing agricultural water use while maintaining or improving economic productivity of the agricultural sector is a major challenge in arid and semiarid regions. Irrigated agriculture is the major consumer of fresh water supplies in many parts of the world, particularly in relatively arid and semiarid regions like Jordan as well as Gulf Cooperation Council (GCC) countries. The demand on scarce water resources in these countries is increasing with time for both agricultural and nonagricultural purposes.

Over recent years, severe shortages in food supplies for livestock have been experienced in Jordan and GCC countries as well as many other countries in the region, mainly, due to repeated droughts as well as shortages of water for irrigation. Many projects to produce forages have been established during the last two decades to cover some green and dry forage needs in these countries. However, scarcity of adequate fresh water supplies might pose challenges for sustainability of the field projects especially with utilizing ground water for irrigation, which is consumed in large amounts as these countries are characterized with very high rates of evapotranspiration and soils of low capacity to retain water. Therefore, methods and technologies that can contribute to improved water use efficiency and productivity merit closer consideration like hydroponic technique.

Hydroponic technique can be used for green fodder production of many forage crops in a hygienic environment free of chemicals like insecticides, herbicides, fungicides, and artificial growth promoters [1-3]. It is a well-known technique for high fodder yield, year round production and least water consumption [3-6]. Unlike field production system that use run-to-waste irrigation practices, the hydroponic fodder system uses recirculation system, thus reducing the waste water. It has been reported that hydroponic fodder production requires only about $2-3 \%$ of that water used under field conditions to produce the same amount of fodder [3]. Fodder produced hydroponically is of a short growth 
period 7-10 days and does not require high-quality arable land, but only a small piece of land for production to take place $[5,7]$. It is of a high feed quality, rich with proteins, fiber, vitamins, and minerals [8-10]. All these special features of hydroponic system, in addition to others make it one of the most important agricultural techniques currently in use for green forage production in many countries especially in arid and semiarid regions of the world. However, determining the best forage crop is an important matter in producing highest fodder yield and quality and at the same time considering the economic dimensions in the process of hydroponic green fodder production by saving of seeds costs.

The objectives of this study were to evaluate five forage crops (alfalfa (Medicago sativa), barley (Hordeum vulgare), cowpea (Vigna unguiculata), sorghum (Sorghum bicolor), and wheat (Triticum aestivum)) for green fodder production and water use efficiency under hydroponic conditions.

\section{Materials and Methods}

This study was conducted under temperature controlled conditions $\left(24 \pm 1{ }^{\circ} \mathrm{C}\right)$ and natural window illumination at growth room of Soilless Culture Laboratory, Sultan Qaboos Center for Developed and Soilless Agriculture, Arabian Gulf University, Manama, Bahrain. A hydroponic system composed from metal frame was designed and assembled from local materials has been used in this study.

2.1. The Hydroponic System. The hydroponic system is composed of two units with metal frame and six shelves each with a length of $265 \mathrm{~cm}$, a width of $46 \mathrm{~cm}$, and a height of $184 \mathrm{~cm}$ (Figure 1). Each shelf of the system unit could carry 6 planting trays with capacity of shelf to produce approximately $15-25 \mathrm{~kg}$ green fodder per growth cycle (810 days), depending on crop, variety, and growth conditions [3]. The horizontal area occupied by each unit of the system was about $1.22 \mathrm{~m}^{2}$. However, more units of the hydroponic system can be assembled and installed to increase the quantity of green fodder production to meet the daily needs of animals in the farm. Plastic trays with a length of $42 \mathrm{~cm}$, a width of $41 \mathrm{~cm}$, and a depth of $6 \mathrm{~cm}$ were used for growing seeds to produce green fodder. These trays were obtained from the local market of Manama, Bahrain. The unit of the hydroponic system has been installed in the growth room close to window (its length extend along the whole wall with two meter height) to utilize natural illumination. An air conditioning was used to control temperature inside the growth room which was maintained at $24 \pm 1^{\circ} \mathrm{C}$. The relative humidity in the growth room ranged between 60 and $70 \%$.

2.2. Plant Material. Five forage crops were evaluated in this study which were: alfalfa (Medicago sativa), barley (Hordeum vulgare), cowpea (Vigna unguiculata), sorghum (Sorghum bicolor), and wheat (Triticum aestivum). Seeds of these crops were obtained from the local market of Manama, Bahrain. Seeds of the five crops were subjected to a germination test to check for their viability before being used; the results of

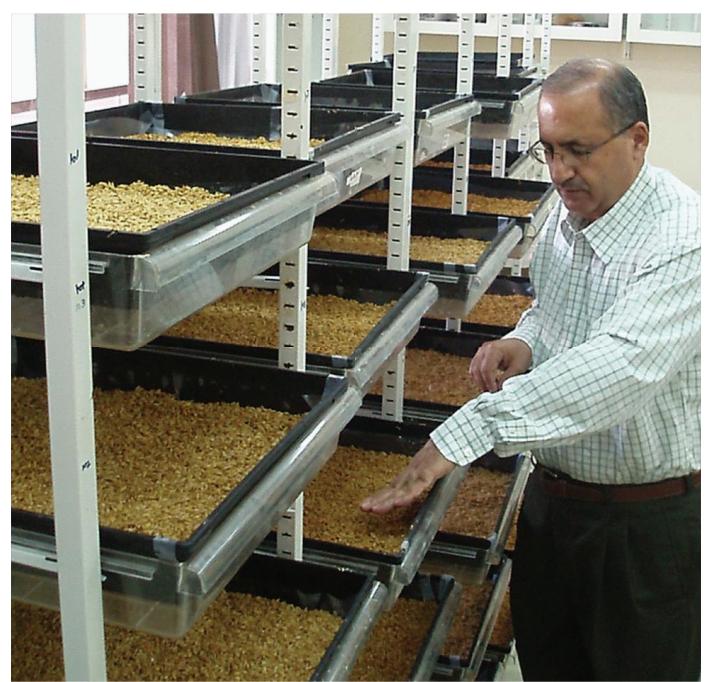

Figure 1: The hydroponic system in which planting trays were stacked after seeding of different crops.

the germination test were $76,73,76,83$, and $78 \%$ for alfalfa, barley, cowpea, sorghum, and wheat, respectively.

2.3. Treatment of Seeds before Planting. Seeds of all crops were cleaned from debris and other foreign materials. Then the cleaned seeds were sterilized by soaking for 30 minutes in a $20 \%$ sodium hypochlorite solution (household bleach) to control the formation of mould. Planting trays were also cleaned and disinfected. The seeds were then washed well from residues of bleach and resoaked in tap water overnight (about 12 hours) before planting.

2.4. Seed Planting and Irrigation. Seeds of all crops were sown in the planting trays which were lined with plastic sheets and have holes at the bottom to allow drainage of excess water from irrigation. The seeding rates used in this experiment were about $300,450,680,550$, and 480 g tray $^{-1}$ for alfalfa, barley, cowpea, sorghum, and wheat, respectively. These rates were based on seeds size and weight to have approximately the same number of plants per tray. The trays were stacked on the shelves ( 36 trays per 6 shelves). Trays were irrigated manually with tap water twice a day (early in the morning and late in the afternoon) at a fixed rate of $600 \mathrm{~mL} \mathrm{tray}^{-1}$ day $^{-1}$ which was enough to keep the seeds/seedlings moist. Drained water out of irrigation was collected in plastic containers which were placed under each planting tray, measured, and recorded to compute for total water use and water use efficiency.

2.5. Fodder Yield. The experiment was terminated after 8 days from seeding, where the fodder biomass was ready for harvest (Figure 2). At harvest time, the following data were recorded per tray: total fresh and dry fodder yields, and ratio of produced green fodder: initial planted seeds weight was computed. A representative fresh plant samples (about 150 grams) from every tray were taken at harvest, oven-dried at 


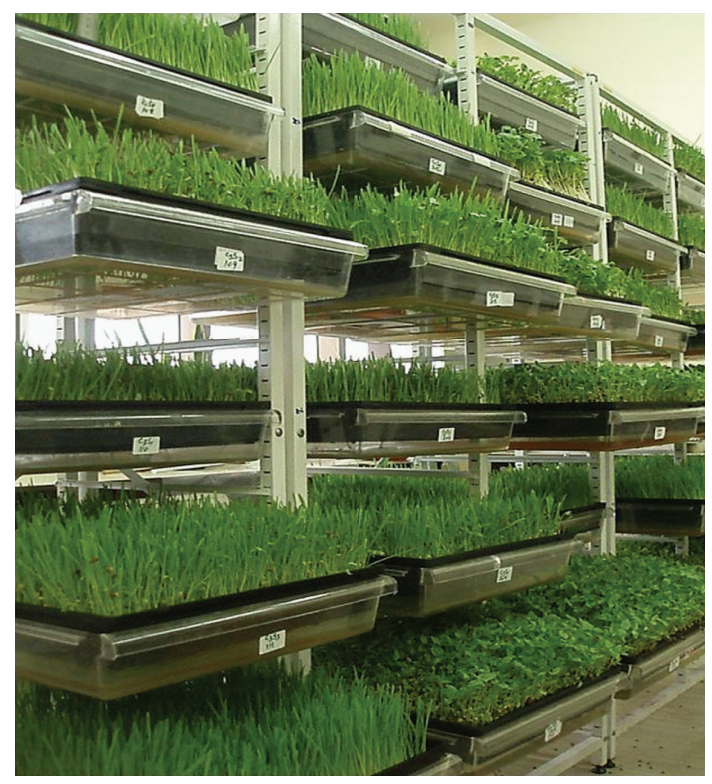

FIGURE 2: Green fodder of different crops ready for harvest.

$70^{\circ} \mathrm{C}$ for 48 hours, and weighed to compute the moisture content.

2.6. Total Water Use and Water Use Efficiency. The total added and drained water out of trays throughout the course of experiment were recorded per tray every day to compute for total water use and water use efficiency.

The total water used by plants (liters/tray) was computed according to the equation:

Total water use $=$ Total added water in irrigation

$$
\text { - Total drained water out of rays. }
$$

Water use efficiency (WUE) in $\mathrm{kg}$ fresh weight $/ \mathrm{m}^{3}$ water was computed according to the equation:

$$
\mathrm{WUE}=\frac{\text { Total green fodder produced }(\mathrm{kg} / \mathrm{tray})}{\text { total water used (liter/tray) }}
$$

2.7. Experimental Design and Statistical Analysis. The completely randomized design was used with four replicates. Data were statistically analyzed using analysis of variance (ANOVA) according to the statistical package MSTAT-C (Michigan State University, East Lansing, MI, USA). Probabilities of significance among treatments (crops) and LSD $(P \leq 0.05)$ were used to compare means among treatments.

\section{Results and Discussion}

Results of this study showed that the green fodder with lush vegetation can be produced in 8 days from planting to harvest using hydroponic technique especially for cowpea and barley crops (Figure 3). Significant differences among tested crops

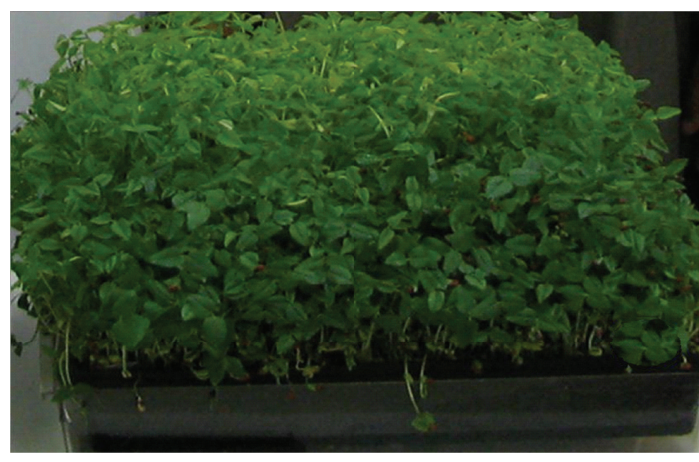

(a)

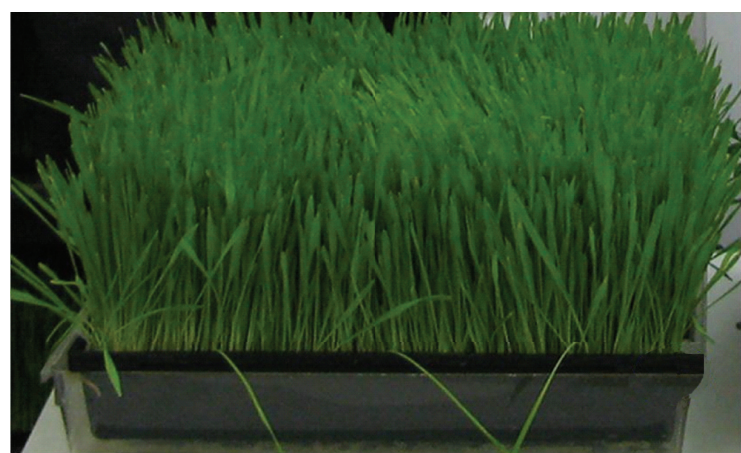

(b)

Figure 3: Green fodder of cowpea (a) and barley (b) gave highest yields among tested crops.

were found in green and dry matter yields (Table 1). Highest values in green fresh yields were recorded in cowpea followed by barley, alfalfa, sorghum, and wheat, respectively (Table 1). However, the differences between the crops barley, cowpea, and alfalfa in green fresh fodder yields were not significant. Genotypic variations in forage yields have been reported for different cereal and legume crops [11]. Average green forage yields were $217,200,194,145$, and 131 tons/ha for one production cycle ( 8 days), for cowpea, barley, alfalfa, sorghum, and wheat, respectively (Table 1 ). A total possible green fodder yield of 5425 and 5000 tons ha ${ }^{-1}$ year $^{-1}$ can be achieved with the hydroponic system (with 25 harvests per year) for cowpea and barley, respectively. Al-Karaki [6] has reported that forage barley grown hydroponically yielded 5600 tons $\mathrm{ha}^{-1}$ year $^{-1}$ under irrigation with tap water.

Results of this study have shown that the dry fodder yield of alfalfa was greatly reduced in comparison to other tested crops (Table 1). This can be attributed to the high moisture content in alfalfa green fodder in comparison to other tested crops $(91.8 \%$ for alfalfa versus $83,85,81$, and $82.5 \%$ for barley, cowpea, sorghum, and wheat, resp.) (Table 1). Barley and cowpea had produced significantly higher dry fodder yields than other tested crops. However, no significant differences between cowpea and barley in dry fodder yields were noted.

Fresh green fodder to initial planted seeds weight ratio values were significantly higher in the alfalfa crop than the other four crops (11.5 for alfalfa versus 7.0 and 5.5 for barley and cowpea, resp.), with no significant differences between 
TABLE 1: Green fodder (fresh), dry yields, and the ratio of produced green fodder: initial planted seeds weight for the studied forage crops under hydroponic conditions.

\begin{tabular}{lcccc}
\hline Crop & $\begin{array}{c}\text { Green fodder yield } \\
\text { Ton/ha }\end{array}$ & $\begin{array}{c}\text { Dry fodder yield } \\
\text { Ton/ha }\end{array}$ & $\begin{array}{c}\text { Moisture content } \\
\%\end{array}$ & $\begin{array}{c}\text { Green fodder: } \\
\text { initial seeds wt }\end{array}$ \\
\hline Alfalfa & $194 \mathrm{a}^{*}$ & $15.9 \mathrm{c}$ & $91.8 \mathrm{a}$ & $11.5 \mathrm{a}$ \\
Barley & $200 \mathrm{a}$ & $34.0 \mathrm{a}$ & $83.0 \mathrm{~b}$ & $7.0 \mathrm{~b}$ \\
Cowpea & $217 \mathrm{a}$ & $32.6 \mathrm{a}$ & $85.0 \mathrm{~b}$ & $5.5 \mathrm{c}$ \\
Sorghum & $145 \mathrm{~b}$ & $27.6 \mathrm{~b}$ & $81.0 \mathrm{~b}$ & $4.5 \mathrm{c}$ \\
Wheat & $131 \mathrm{~b}$ & $22.9 \mathrm{~b}$ & $82.5 \mathrm{~b}$ & $4.7 \mathrm{c}$ \\
\hline
\end{tabular}

${ }_{\S}^{8}$ Based on one production cycle (8 days).

* Means for each trait followed by the same letter are not significantly different at $P \leq 0.05$ according to the least significant difference (LSD) test.

TABLE 2: Water use and water use efficiency of barley cultivars grown under hydroponic conditions.

\begin{tabular}{lcccc}
\hline \multirow{2}{*}{ Crop } & \multicolumn{2}{c}{ Total water use } & \multicolumn{2}{c}{ Water use efficiency } \\
& Liters/tray & Liters $/ \mathrm{kg}$ fresh matter & Kg fresh matter/m & \multicolumn{2}{c}{$\mathrm{Kg} \mathrm{dry} \mathrm{matter/m}^{3}$} \\
\hline Alfalfa & $6.4 \mathrm{a}$ & $1.92 \mathrm{a}$ & $521 \mathrm{c}$ & $43 \mathrm{~b}$ \\
Barley & $5.3 \mathrm{~b}$ & $1.55 \mathrm{c}$ & $645 \mathrm{a}$ & $110 \mathrm{a}$ \\
Cowpea & $5.9 \mathrm{a}$ & $1.58 \mathrm{c}$ & $633 \mathrm{a}$ & $95 \mathrm{a}$ \\
Sorghum & $4.3 \mathrm{c}$ & $1.71 \mathrm{~b}$ & $585 \mathrm{~b}$ & $111 \mathrm{a}$ \\
Wheat & $4.1 \mathrm{c}$ & $1.80 \mathrm{~b}$ & $552 \mathrm{~b}$ & $97 \mathrm{a}$ \\
\hline
\end{tabular}

${ }^{*}$ Means for each trait of hydroponic barley followed by the same letter are not significantly different at $P \leq 0.05$ according to the least significant difference (LSD) test.

barley and cowpea (Table 1). Similar or lower values were obtained by researchers on other studies on barley crop $[2,3,12]$.

Water is one of the basic requirements for seed germination and seedling growth as it is essential for enzyme activation, reserve storage breakdown, translocation, and use in seed germination and seedling growth [13]. Hydroponically produced fodder was found to enhance the efficiency of water use (WUE). Bradley and Marulanda [14] reported that hydroponic green fodder production technique requires only about $10-20 \%$ of the water needed to produce the same amount of crop in soil culture. While Al-Karaki and AlMomani [3] reported that only $3-5 \%$ of water is needed to produce the same amount of fodder in comparison to that produced under field conditions. In this study, barley and cowpea crops were found to use water more efficiently than the other tested crops when used only 1.55 and $1.58 \mathrm{~m}^{3}$ water, respectively, to produce 1 ton of hydroponic green fodder in comparison to $1.71,1.80$, and $1.92 \mathrm{~m}^{3}$ water in sorghum, wheat, and alfalfa, respectively (Table 2 ). Similar data were reported by other researchers $[3,6]$.

Producing green fodders under hydroponic conditions is a highly efficient process in terms of water saving when compared to field production of green fodders. When comparison is made with barley and alfalfa crops grown under field conditions, Al-Karaki and Al-Momani [3] reported that water use efficiency (WUE) of only 14 and $12 \mathrm{Kg}$ forage fresh matter $/ \mathrm{m}^{3}$ water for field irrigated barley and alfalfa, respectively, compared to that of 645 and $521 \mathrm{~kg}$ fresh matter $/ \mathrm{m}^{3}$ water in barley and alfalfa obtained in this study, respectively (Table 2 ). This is a tremendous improvement in
WUE and indicated that hydroponic system could play a significant role in improving water use efficiency in countries that suffer from scarcity of water like Jordan and GCC countries.

\section{Conclusions}

From results of this study, it can be concluded that the barley and cowpea crops showed better fodder production and WUE under hydroponic conditions than the other tested crops. However, barley crop is considered the best choice that can be used for production of hydroponic green fodder with less water consumption; especially seeds of this crop are mostly available in the market at lower price than others which reduce the cost of hydroponic fodder production.

\section{Acknowledgment}

The senior author is grateful to the Arabian Gulf University (AGU)/Bahrain for providing the facilities to conduct this research during his assignment with AGU.

\section{References}

[1] M. H. Jensen and A. J. Malter, "Protected agriculture: a global review," World Bank Technical Paper 253, 1995.

[2] M. M. Al-Hashmi, Hydroponic green fodder production in the Arabian Gulf Region, M.S. thesis, Faculty of Graduate Studies, Arabian Gulf University, Manama, Bahrain, 2008.

[3] G. N. Al-Karaki and N. Al-Momani, "Evaluation of some barley cultivars for green fodder production and water use 
efficiency under hydroponic conditions," Jordan Journal of Agricultural Sciences. In press.

[4] G. Tudor, T. Darcy, P. Smith, and F. Shallcross, "The in take and liveweight change of drought master steers fed hydroponically grown, young sprouted barley fodder (Autograss)," Department of Agriculture Western Australia, 2003.

[5] D. Cuddeford, "Hydroponic grass," In Practice, vol. 11, no. 5, pp. 211-214, 1989.

[6] G. N. Al-Karaki, "Utilization of treated wastewater for green forage production in a hydroponic system," Emirates Journal of Food and Agriculture, vol. 23, pp. 80-94, 2011.

[7] J. Mooney, "Growing cattle feed hydroponically," Meat and livestock Australia, 2005.

[8] V. Bhise, J. Chavan, and S. Kadam, "Effects of malting on proximate composition and in vitro protein and starch digestibilities of grain sorghum," Journal of Food Science and Technology, vol. 25, no. 6, pp. 327-329, 1988.

[9] T. Y. Chung, E. N. Nwokolo, and J. S. Sim, "Compositional and digestibility changes in sprouted barley and canola seeds," Plant Foods for Human Nutrition, vol. 39, no. 3, pp. 267-278, 1989.

[10] K. Lorenz, "Cereal sprouts: composition, nutritive value, food applications," Critical Reviews in Food Science and Nutrition, vol. 13, no. 4, pp. 353-385, 1980.

[11] M. Ansar, Z. I. Ahmed, M. A. Malik, M. Nadeem, A. Majeed, and B. A. Rischkowsky, "Forage yield and quality potential of winter cereal-vetch mixtures under rainfed conditions," Emirates Journal of Food and Agriculture, vol. 22, no. 1, pp. 2536, 2010.

[12] N. H. Al-Momani, Application of treated wastewater in green fodder production under hydroponic conditions in Jordan, M.S. thesis, Faculty of Graduate Studies, Jordan University of Science and technology, Irbid, Jordan, 2010.

[13] O. L. Copeland and M. B. Mcdonald, Seed Science and Technology, Chapman and Hall, New York, NY, USA, 3rd edition, 1995.

[14] P. Bradley and C. Marulanda, "Simplified hydroponics to reduce global hunger," Acta Horticulture, vol. 554, pp. 289 295,2000 . 


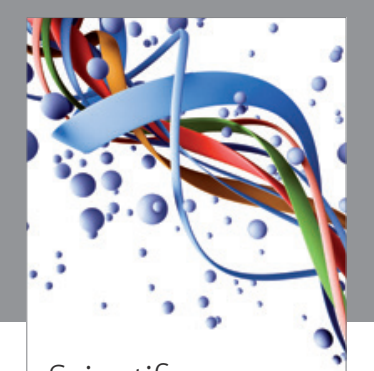

Scientifica
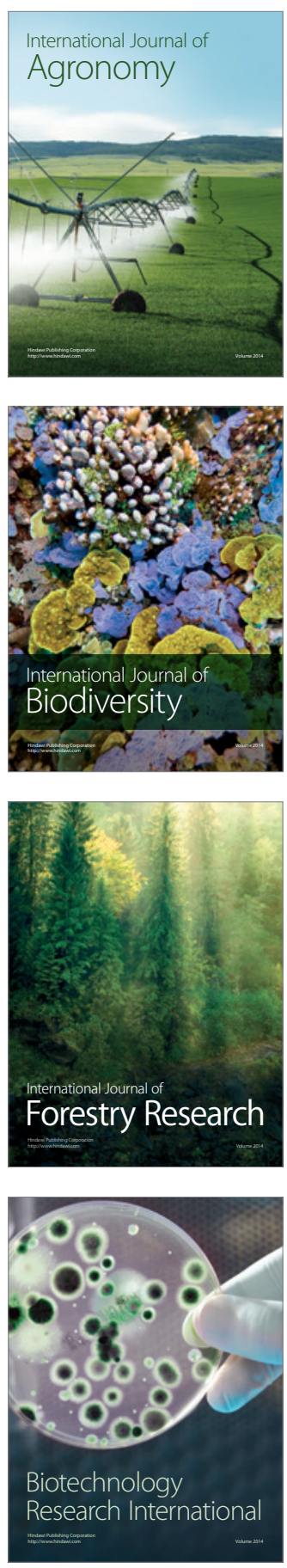
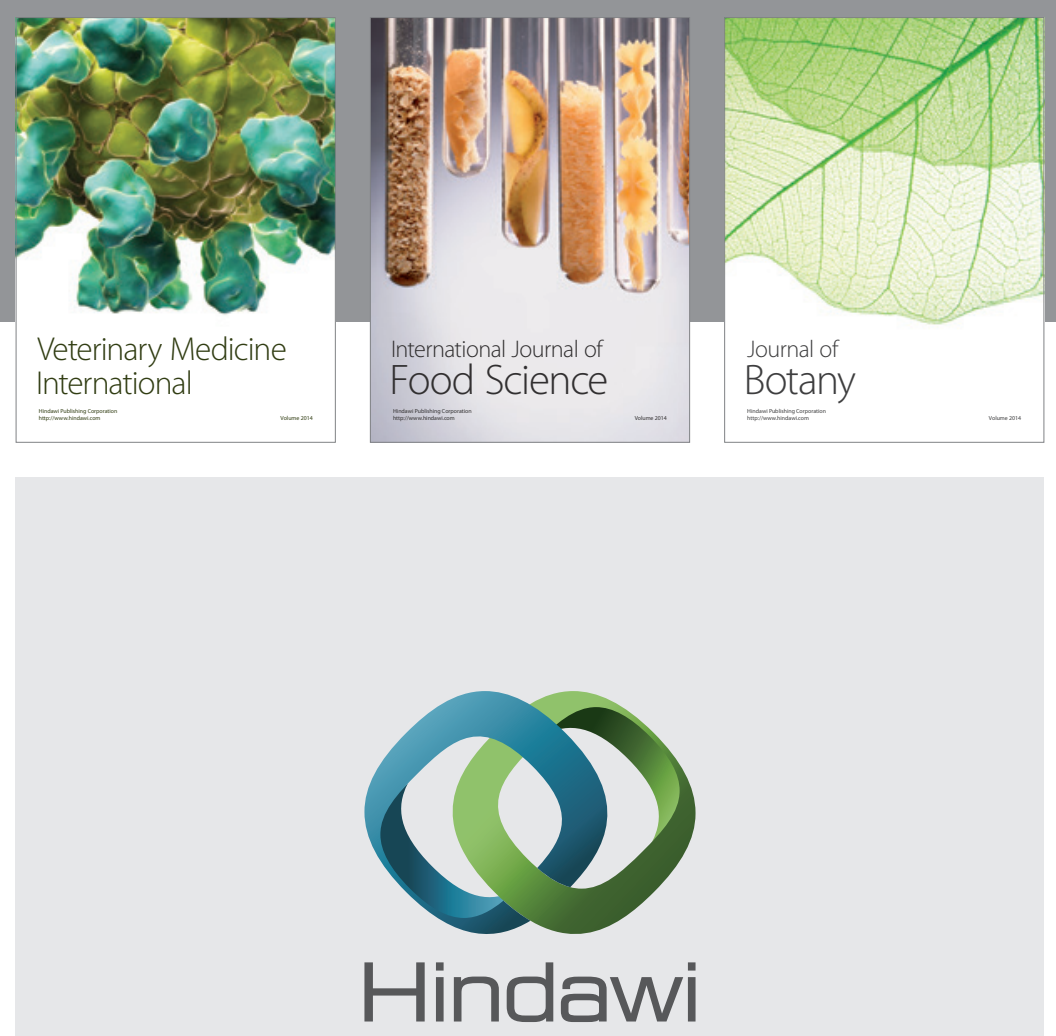

Submit your manuscripts at

http://www.hindawi.com
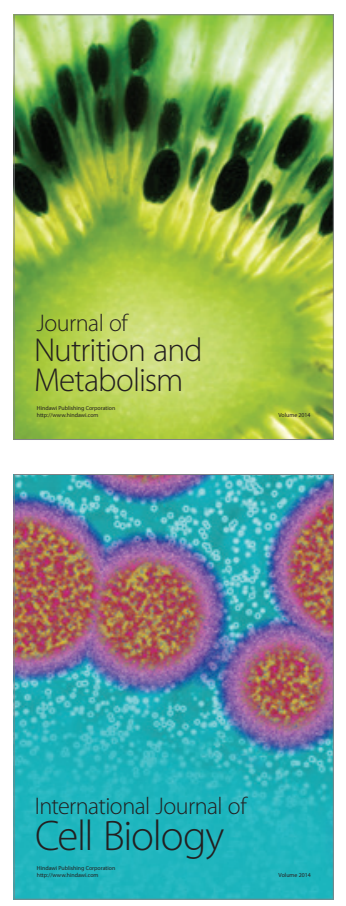
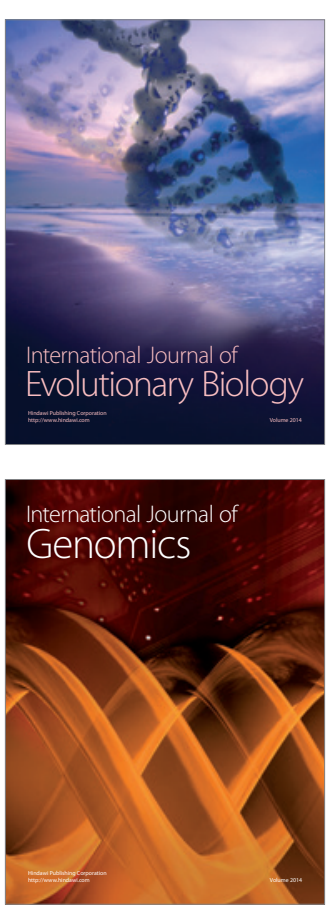
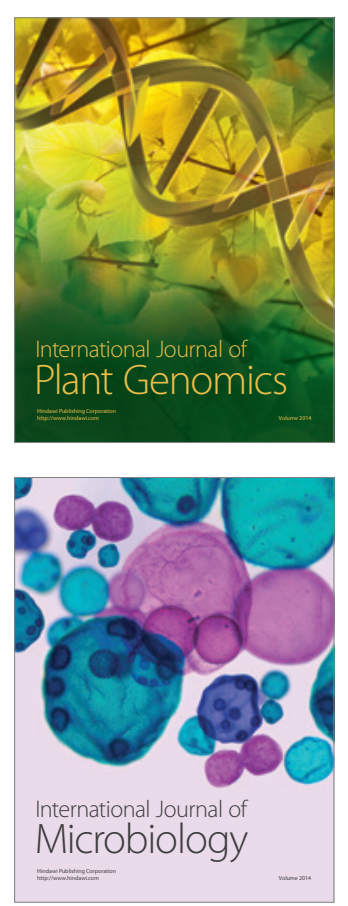

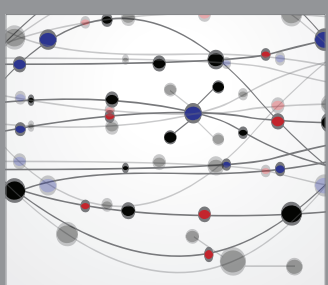

The Scientific World Journal
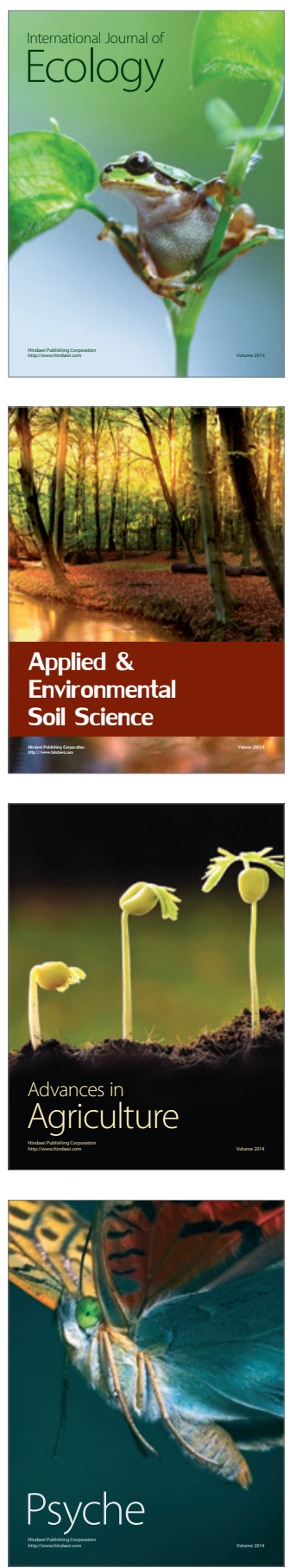